\title{
PEMBELAJARAN IPA MELALUI PENDEKATAN KONTEKSTUAL MENGGUNAKAN SIMULASI KOMPUTER DAN MODEL KERJA DITINJAU DARI KEMAMPUAN BERPIKIR KRITIS DAN GAYA BELAJAR
}

\author{
${ }^{1}$ Suci Rahayu, ${ }^{2}$ Sugiyarto, dan ${ }^{3}$ Widha Sunarno \\ ${ }^{1}$ Sekolah Menengah Pertama Negeri 3 Magetan \\ Magetan, 63311, Indonesia \\ oetjie08@yahoo.com \\ ${ }^{2}$ Program Studi Pendidikan Sains, Program Pascasarjana, Universitas Sebelas Maret Surakarta \\ Surakarta, 57126, Indonesia \\ sugiyarto_ys@yahoo.com \\ ${ }^{3}$ Program Studi Pendidikan Sains, Program Pascasarjana, Universitas Sebelas Maret Surakarta \\ Surakarta, 57126, Indonesia \\ widhasunarno@gmail.com
}

\begin{abstract}
Abstrak
Penelitian ini bertujuan mengetahui pengaruh pembelajaran IPA melalui pendekatan kontekstual menggunakan simulasi komputer dan model kerja, kemampuan berpikir kritis dan gaya belajar terhadap prestasi belajar. Penelitian ini merupakan penelitan kuasi eksperimen, dilaksanakan pada bulan Maret 2012 - Januari 2013. Populasi penelitian adalah siswa kelas VIII SMP Negeri 3 Magetan Tahun Pelajaran 2012/2013. Sampel penelitian ada 4 kelas terbagi dua kelompok yang diambil dengan cara cluster random sampling. Kelas VIII A dan VIII H menggunakan media simulasi komputer dan kelas VIII B dan VIII C menggunakan media model kerja. Data dikumpulkan dengan metode tes untuk kemampuan berpikir kritis dan prestasi belajar kognitif, angket untuk gaya belajar, prestasi afektif, prestasi psikomotor, dan lembar observasi untuk prestasi belajar afektif dan psikomotor. Hipotesis diuji menggunakan anava tiga jalan, uji lanjut Anava uji Scheffe, desain faktorial $2 \times 2 \times 2$. Berdasarkan hasil analisis data disimpulkan: 1) pembelajaran IPA melalui pendekatan kontekstual menggunakan media simulasi komputer dan model kerja berpengaruh terhadap prestasi belajar kognitif, afektif, dan psikomotor; 2) kemampuan berpikir kritis berpengaruh terhadap prestasi belajar kognitif, afektif, dan psikomotor; 3) gaya belajar berpengaruh terhadap prestasi belajar kognitif, afektif, dan psikomotor; 4) tidak ada pengaruh yang signifikan dari interaksi antara media dan kemampuan berpikir kritis terhadap prestasi belajar kognitif, afektif, dan psikomotor; 5) ada pengaruh yang signifikan dari interaksi antara media dan gaya belajar terhadap prestasi belajar kognitif, afektif, dan psikomotor; 6) tidak ada pengaruh yang signifikan dari interaksi antara kemampuan berpikir kritis dengan gaya belajar terhadap prestasi belajar kognitif, afektif, dan psikomotor; 7) tidak ada pengaruh yang signifikan dari interaksi antara media, kemampuan berpikir kritis, dan gaya belajar terhadap prestasi belajar kognitif, afektif, dan psikomotor.
\end{abstract}

Kata Kunci: simulasi komputer, model kerja, kemampuan berpikir kritis, gaya belajar, prestasi belajar.

\section{Pendahuluan}

Ilmu pengetahuan dan teknologi diperoleh dari proses pembelajaran berkualitas, khususnya mata pelajaran Ilmu Pengetahuan Alam (IPA) yang diperlukan dalam kehidupan sehari-hari untuk memenuhi kebutuhan manusia melalui pemecahan masalah-masalah yang diidentifikasikan. Dalam Permendiknas nomor
22 tahun 2006 tentang Standar Isi, dijelaskan bahwa pembelajaran IPA sebaiknya dilaksanakan secara inkuiri untuk menumbuhkan kemampuan berpikir, bekerja dan bersikap ilmiah serta mengkomunikasikannya sebagai aspek penting kecakapan hidup. Oleh karena itu pembelajaran IPA di SMP/MTs menekankan pada pemberian pengalaman belajar secara langsung melalui penggunaan dan pengembangan ketrampilan 
proses dan sikap ilmiah. Sanjaya (2011) menjelaskan bahwa salah satu masalah yang dihadapi pendidikan di Indonesia adalah lemahnya proses pembelajaran. Dalam proses pembelajaran, siswa kurang didorong untuk mengembangkan kemampuan berpikir. Selama ini mata pelajaran IPA belum dapat mengembangkan kemampuan siswa untuk berpikir kritis dan sistematis.

Pendekatan pembelajaran yang tepat dapat mendukung keberhasilan proses pembelajaran di kelas dalam mencapai tujuan pembelajaran pada suatu kompetensi dasar. Pendekatan pembelajaran dirancang karena adanya kebutuhan untuk meyakinkan: (1) ada alasan untuk belajar; (2) siswa belum mengetahui makna yang diajarkan, oleh karena itu guru menetapkan hasil-hasil belajar atau tujuan yang diharapkan akan dicapai (Sagala, 2011). Pendekatan kontekstual merupakan pendekatan pembelajaran yang dirancang untuk mengaitkan antara materi pelajaran dengan pengetahuan yang dimiliki siswa dalam kehidupan sehari-hari, hingga siswa sadar bahwa yang dipelajarinya berguna bagi hidupnya. Pendekatan kontekstual dapat meningkatkan keterlibatan siswa dalam proses pembelajaran dan daya ingat siswa juga semakin baik (Oka, 2011).

Selama ini, pembelajaran IPA di SMP Negeri 3 Magetan belum menunjukkan pendekatan pembelajaran yang jelas. Pada umumnya guru melakukan pembelajaran secara konvensional dan belum menyadari pentingnya penggunaan pendekatan pembelajaran. Materi yang diajarkan kepada siswa hanya merupakan transfer pengetahuan dari guru kepada siswa, sehingga siswa menganggap pelajaran IPA adalah mata pelajaran yang sulit dan siswa belum menyadari pentingnya materi pelajaran tersebut dalam kehidupan sehari-hari. Belajar dalam bentuk masyarakat belajar belum menjadi budaya belajar di kelas. Siswa lebih banyak diberi tugastugas individual, sehingga kemampuan untuk mengeluarkan pendapat dan menghargai pendapat orang lain belum terlatih.

Pendekatan kontekstual dilakukan dengan melibatkan komponen utama pembelajaran yang efektif yakni: (1) konstruktivisme; (2) bertanya; (3) inkuiri; (4) masyarakat belajar; (5) pemodelan; (6) refleksi; dan (7) penilaian sebenarnya (Muslich, 2007). Dari ketujuh komponen tersebut, konstruktivisme merupakan filosofi pendekatan kontekstual. Didukung dengan pemilihan media yang tepat akan lebih mengefektifkan proses membangun pengetahuan. Pengalaman belajar yang diperoleh siswa dapat melalui proses mengalami sendiri dan proses mengamati menggunakan media tertentu.

Kelompok mata pelajaran ilmu pengetahuan dan teknologi di SMP/MTs/SMPLB dimaksud untuk memperoleh kompetensi lanjut ilmu pengetahuan dan teknologi serta membudayakan berpikir ilmiah secara kritis, kreatif, dan mandiri. Pemanfaatan Teknologi Informasi dan Komunikasi (TIK) di sekolah adalah salah satu upaya untuk meningkatkan mutu pendidikan.

Keadaan di SMP Negeri 3 Magetan, media pembelajaran berbasis TIK belum banyak dikembangkan dan dimanfaatkan. Sarana prasarana untuk melaksanakannya sudah cukup memadai karena di SMP Negeri 3 Magetan sudah memiliki laboratorium multimedia, namun belum dimanfaatkan secara maksimal. Selama ini laboratorium multimedia hanya digunakan oleh guru-guru mata pelajatan TIK. Sedangkan guruguru mata pelajaran lain, khususnya guru mata pelajaran IPA belum memanfaatkannya. Pesatnya perkembangan TIK, menuntut guru untuk mengikuti kemajuan zaman. Pemanfaatan media pembelajaran berbasis TIK sangat menunjang proses belajar mengajar IPA. Holzinger (2008) menjelaskan hasil penelitiannya, bahwa media dinamik dan multimedia menjadi popular, berhasil lebih memfasilitasi pembelajaran dibanding dengan media statis tardisional seperti teks atau gambar.

Penggunaan media pembelajaran berbasis TIK dalam bentuk simulasi komputer merupakan salah satu strategi pembelajaran yang bertujuan memberikan pengalaman belajar lebih nyata melalui penciptaan tiruan-tiruan bentuk yang mendekati suasana yang sebenarnya (Indriana, 2011), bertumpu pada gambaran visualisasi dari fenomena model, sehingga menolong siswa untuk memahami informasi dan menyusun pemahaman (Lee et al. 2006). Media simulasi komputer mempunyai beberapa keuntungan: (1) memberikan kesempatan untuk belajar secara dinamis dan interaktif; (2) lingkungan pekerjaan yang kompleks dapat ditata hingga menyerupai dunia nyata (Arsyad, 2011); (3) meningkatkan proses belajar dengan memberikan kesempatan bagi siswa untuk mengembangkan keterampilan, mengidentifikasi masalah, mengorganisasi, menganalisis, mengevaluasi, dan mengkomunikasikan informasi. Hal ini dapat 
memotivasi dan menyenangkan siswa dalam proses pembelajaran. Namun kondisi pada saat ini banyak guru SMP Negeri 3 Magetan yang kurang dalam hal literasi TIK, sehingga jarang yang menggunakan sarana prasarana TIK dalam proses pembelajarannya.

Sanaky (2011) menyatakan model atau benda tiruan working model (model kerja) dapat digunakan untuk mendemonstrasikan fungsi atau proses-proses. Model kerja mempunyai keunggulan sangat membantu dalam mewujudkan realitas yang bisa dilihat dan dipegang. Menurut Samani (2007), jika guru dapat mengaitkan materi yang dibahas dengan kondisi siswa, baik hobi maupun kebutuhan siswa, perkembangan kognitif, lingkungan keseharian dan bekal awal yang telah dimiliki siswa, maka pola ini yang disebut pembelajaran kontekstual. Siswa mampu merangkai media pembelajaran dan mengkondisikan proses pembelajaran yang berpusat pada siswa dapat memotivasi siswa untuk belajar.

Di SMP Negeri 3 Magetan sudah tersedia beraneka macam media, baik dalam bentuk multimedia, alat-alat laboratorium, dan media lingkungan, tetapi pada umumnya guru kurang kreatif menggunakan media pembelajaran. Hal ini dikuatkan oleh Sutjiono (2005) yang menjelaskan beberapa alasan guru tidak menggunakan media pembelajaran: (1) menggunakan media itu repot; (2) media itu canggih dan mahal; (3) tidak bisa; (4) media itu hiburan (membuat murid main-main, tidak serius); (5) tidak tersedia; (6) kebiasaan menikmati ceramah/bicara; (7) kurangnya penghargaan dari atasan.

Faktor internal yang mempengaruhi proses belajar siswa belum banyak diperhatikan oleh guru, antara lain: kondisi jasmaniah, IQ maupun EQ, minat belajar, motivasi, krativitas, kemampuan berpikir dan gaya belajar. Faktorfaktor tersebut dapat menimbulkan masalah apabila kurang mendapat perhatian guru. Guru menganggap semua siswa mempunyai kemampuan yang sama dalam proses belajar. Kemampuan berpikir kritis dan gaya belajar siswa belum mendapat perhatian yang serius dari guru. Hal ini diindikasikan dengan kegiatan pembelajaran IPA di SMP Negeri 3 Magetan yang banyak dilakukan secara konvensional dan kurang bervariasinya media pembelajaran yang digunakan.
Proses pembelajaran IPA perlu sikap ilmiah dan proses ilmiah untuk mendapatkan produk ilmiah yang berupa fakta, konsep, dan teori. Komponen sikap ilmiah yang perlu ditumbuhkan antara lain keingintahuan, tanggung jawab, jujur, terbuka, obyektif, toleransi, kerja keras, cermat, dan disiplin. Proses ilmiah merupakan keterampilan yang digunakan siswa dalam melakukan pembelajaran IPA melalui proses penemuan, berhipotesis melalui pengamatan dan menyimpulkan. Hal semacam ini disebut dengan kemampuan berpikir kritis. Kemampuan berpikir kritis akan membentuk pemahaman dengan mengolah pengetahuan yang mendalam menghadapi masalah sehari-hari (Murwani, 2006). Sesuai dengan karakteristik mata pelajaran IPA yang mengutamakan proses intelektual aktif melalui hasil observasi dan komunikasi hingga siswa dapat menemukan sendiri konsep atau fakta. Redhana (2003) menjelaskan bahwa aktifitas belajar dan keemampuan berikir kritis siswa dapat ditingkatkan melalui penerapan pembelajaran kooperatif dengan strategi pemecahan masalah.

Media pembelajaran yang beraneka ragam dalam mata pelajaran IPA dapat digunakan untuk menyalurkan pesan, merangsang pikiran, perhatian, dan minat siswa sehingga terjadi proses belajar. Cara siswa menyerap informasi dengan mudah menggunakan inderanya yang paling peka disebut dengan gaya belajar. Seorang guru hendaknya tahu gaya belajar siswanya, visual, auditori atau kinestetik. Pemanfaatan media kurang bervariasi dan kurang memotivasi siswa untuk berpikir kritis, karena pembelajaran dilaksanakan dengan teacher center.

Aspek kognitif siswa SMP yang berusia 11 tahun hingga dewasa, mulai sanggup berpikir abstrak dan melihat sejumlah kemungkinan. Tahap ini disebut tahap operasional formal (Inhelder dan Piaget, 1958 cit Slavin, 2011). Pada usia ini, perkembangan berpikir siswa cenderung secara simbolis dan bisa memahami sesuatu secara bermakna, namun pada siswa SMP masa ini merupakan masa peralihan dari masa kanak-kanak menuju dewasa. Pada kondisi tertentu, seorang siswa memerlukan bantuan teman yang lebih kompeten atau orang dewasa dalam proses belajarnya. Vygotsky cit Yususf dan Sugandi (2011), menyebutkan tahap perkembangan ini sebagai zona perkembangan proksimal. Pandangan dua ahli tersebut 
mengarahkan pada perlunya proses belajar dalam masyarakat belajar, yang merupakan salah satu komponen pendekatan kontekstual. Perkembangan kognitif siswa dan masyarakat belajar belum mendapat perhatian yang serius dari guru IPA di SMP Negeri 3 Magetan, karena kebanyakan guru lebih suka mengajar dengan berceramah.

Kompetensi dasar sistem pernapasan pada manusia dipandang perlu untuk diteliti dengan proses pembelajarannya menggunakan media simulasi dan media model kerja karena berhubungan erat dengan: kehidupan sehari-hari, kompleksitas materinya tinggi, hukum Boyle, dan materi kimia pada reaksi katabolisme. Proses bernapas tidak dapat diamati secara langsung, sehingga membutuhkan media untuk memvisualisasikannya.

Selama proses pembelajaran bermakna, perlu diadakan proses evaluasi yang merupakan serangkaian kegiatan untuk memperoleh, menganalisis dan menafsirkan proses dan hasil belajar siswa. Tujuan evaluasi adalah untuk menentukan kemajuan belajar siswa (Purwanto, 2009), maka proses evaluasi yang dilakukan secara sistematis dan berkesinambungan menjadi informasi yang bermakna dalam pengambilan keputusan untuk menentukan tingkat keberhasilan pencapaian kompetensi siswa sesuai dengan standar yang telah ditentukan. Proses evaluasi hendaknya disesuaikan dengan karakteristik mata pelajaran IPA dan dilakukan secara komprehensif terhadap aspek kognitif, afektif, dan psikomotor. Namun kenyataan yang ada, sistem penilaian yang diterapkan di SMP Negeri 3 Magetan hanya mengacu pada aspek kognitif saja. Guru mengabaikan penilaian autentik yang digunakan untuk mengetahui kemajuan dan hasil belajar siswa. Seharusnya penilaian autentik menyatu dalam proses belajar mengajar.

Berdasarkan latar belakang dan upaya mengatasi permasalahan pembelajaran di SMP Negeri 3 Magetan perlu dilakukan penelitian dengan judul "Pembelajaran IPA Melalui Pendekatan Kontekstual Menggunakan Simulasi Komputer dan Model Kerja Ditinjau dari Kemampuan Berpikir Kritis dan Gaya Belajar". Tujuan yang akan dicapai penelitian ini adalah untuk mengetahui pengaruh pendekatan kontekstual menggunakan simulasi komputer dan model kerja, kemampuan berpikir kritis, gaya belajar dan interaksinya terhadap prestasi belajar siswa.

\section{Metode Penelitian}

Penelitian dilaksanakan di SMPN 3 Magetan. Waktu penelitian dimulai bulan Maret 2012 sampai dengan bulan Januari 2013. Jenis penelitian ini kuasi eksperimen, dengan rancangan penelitian menggunakan anava tiga jalan dan desain faktorial $2 \times 2 \times 2$.

Instrumen penelitian berupa silabus, Rencana Pelaksanaan Pembelajaran (RPP) dan Lembar Kegiatan Siswa (LKS) untuk media simulasi komputer dan model kerja. Instrumen pengambilan data menggunakan tes hasil belajar lembar observasi, dan angket. Teknik pengumpulan data menggunakan: (1) observasi, untuk prestasi belajar aspek afekttif dan psikomotor, (2) kuisioner, untuk memperoleh data kemampuan berpikir kritis dan gaya belajar sebelum kegiatan pembelajaran, data prestasi kognitif setelah proses kegiatan belajar mengajar. Teknik pengambilan sampel yang digunakan adalah cluster random sampling. Sampel yang digunakan dalam penelitian ini ada 4 kelas, yaitu kelas VIII A dan VIII H sebagai kelas eksperimen I menggunakan media simulasi komputer dan kelas VIII B dan VIII C sebagai kelas eksperimen II menggunakan media model kerja.

Instrumen, media dan materi pembelajaran yang mendukung penelitian ini divalidasi oleh dua validator dari bidang ilmu yang relevan dalam hal konstruksi dan keterbacaan instrumen. Uji coba instrumen di SMP Negeri 2 Magetan, dilakukan uji validitas dan reliabilitas. Uji prasyarat analisis dilakukan dengan uji normalitas dan uji homogenitas. Data prestasi kognitif, afeltif dan psikomotor yang diperoleh dianalisis menggunakan uji anava tiga jalan.

\section{Hasil Penelitian dan Pembahasan}

Tabel 1 menunjukkan rangkuman hasil anava pada prestasi belajar kognitif, afektif dan psikomotor:

Tabel 1. Rangkuman Uji Anava

\begin{tabular}{|c|c|c|c|c|}
\hline \multirow{3}{*}{ No. } & \multirow{3}{*}{ Variabel } & \multicolumn{3}{|c|}{ P-value } \\
\hline & & \multicolumn{3}{|c|}{ Prestasi Beajar } \\
\hline & & Kognitif & Afektif & Psikomotor \\
\hline 1 & Media & 0,041 & 0,000 & 0,000 \\
\hline 2 & Berpikir Kritis & 0,000 & 0,002 & 0,001 \\
\hline 3 & Gaya Belajar & 0,000 & 0,005 & $\mathbf{0 , 0 0 0}$ \\
\hline 4 & $\begin{array}{l}\text { Metode*Berpikir } \\
\text { Kritis }\end{array}$ & 0,093 & 0,685 & 0,516 \\
\hline 5 & Metode*Gaya Belajar & 0,019 & 0,012 & 0,043 \\
\hline 6 & Berpikir Kritis* & 0,196 & 0,601 & 0,505 \\
\hline
\end{tabular}




\begin{tabular}{llll} 
& $\begin{array}{l}\text { Komunikasi Verbal } \\
\text { Metode*Berpikir }\end{array}$ \\
7 & $\begin{array}{l}\text { Kritis*Komunikasi } \\
\text { Verbal }\end{array}$ & $0,815 \quad 0,391$ & 0,593 \\
\hline Ket : *) signifikan pada uji Anava dengan $\alpha$ & $0,05$. & \\
\hline 1.
\end{tabular}

1. Pengaruh pendekatan kontekstual menggunakan simulasi komputer dan model kerja terhadap prestasi belajar.

Hasil penelitian menunjukkan bahwa simulasi komputer dan model kerja berpengaruh secara signifikan terhadap prestasi belajar kognitif, afektif dan psikomotorik. Deskripsi data pestasi belajar kognitif, afektif dan psikomotorik pada penggunaan media disajikan pada Tabel 2 .

Tabel 2. Deskripsi Data Prestasi Belajar Kognitif, Afektif dan Psikomotor pada Penggunaan Media

\begin{tabular}{crrc}
\hline \multicolumn{2}{c}{ Media } & \multicolumn{3}{c}{ Rata-rata Prestasi Belajar } \\
& Kognitif & Afektif & Psikomotor \\
\hline Simulasi Komputer & 66,52 & 76,60 & 80,76 \\
Model Kerja & 70,69 & 78,33 & 82,80 \\
\hline
\end{tabular}

Siswa yang diberi pembelajaran dengan

pendekatan kontekstual menggunakan model kerja mempunyai nilai rata-rata prestasi belajar yang lebih baik dari siswa yang menggunakan simulasi komputer. Hal ini disebabkan media model kerja lebih menarik karena siswa dapat membuat sendiri dan mengoperasikan secara langsung sistem kerjanya model alat pernapasan yang menyerupai alat sebenarnya.

Edgar Dale cit Arsyad (2011) memandang nilai media pembelajaran diklasifikasikan berdasarkan pengalaman belajar dengan nama kerucut pengalaman (cone of experience), menjelaskan bahwa tingkat pengalaman yang paling tinggi nilainya adalah pengalaman yang paling konkrit. Model kerja merupakan media dalam bentuk tiga dimensi lebih nyata daripada simulasi komputer. Sudiyono (2011) dalam penelitiannya, mendapatkan simpulan bahwa peningkatan hasil belajar dengan media model adalah 20,87\% lebih tinggi bila dibandingkan dengan pembelajaran ceramah.

Gokhale (1996) dalam penelitiannya menjelaskan bahwa aktivitas simulasi komputer dapat digunakan sebagai alternatif pembelajaran untuk membantu motivasi siswa dalam proses menemukan sendiri dan perkembangan kemampuan nalar siswa. Sejalan dengan penelitian Wiyono dan Taufiq (2010) yang menyimpulkan bahwa penggunaan simulasi komputer meningkatkan konsep disebabkan simulasi dapat membantu memvisualisasikan materi yang bersifat abstrak. Namun siswa yang menggunakan media simulasi komputer, menerima informasi visualisasi alat dan proses pernapasan manusia tetapi kurang nyata.

2. Pengaruh kemampuan berpikir kritis tinggi dan rendah terhadap prestasi belajar.

Hasil penelitian menunjukkan bahwa terdapat pengaruh yang signifikan antara kemampuan berpikir kritis tinggi dan rendah terhadap prestasi belajar kognitif, afektif, dan pikomotor. Deskripsi data prestasi belajar kognitif, afektif dan psikomotor berdasarkan kemampuan beprikir kritis disajikan pada Tabel 3.

Tabel 3. Deskripsi Data Prestasi Belajar Kognitif, Afektif dan Psikomotor Berdasar Kemampuan Berpikir Kritis

\begin{tabular}{lrrc}
\hline Kemampuan & \multicolumn{3}{c}{ Rata-rata Prestasi Belajar } \\
Berpikir Kritis & Kognitif & Afektif & Psikomotor \\
\hline Tinggi & 72,42 & 78,82 & 83,14 \\
Rendah & 64,20 & 76,02 & 80,11 \\
\hline \multicolumn{1}{c}{ Sis }
\end{tabular}

Siswa yang mempunyai kemampuan berpikir kritis tinggi memunyai nilai rata-rata prestasi belajar yang lebih baik daripada siswa dengan kemampuan berpikir kritis rendah. Berpikir kritis dengan jelas menuntut interpretasi dan evaluasi terhadap observasi, komunikasi dan sumber-sumber informasi lainnya. Siswa yang mempunyai kemampuan berpikir kritis tinggi mampu menginterpretasi, menganalisis, mengevaluasi gagasan dan argumen masalah-masalah yang dihubungakan dengan kehidupan sehari-hari. Sedangkan siswa yang mempunyai kemampuan berpikir kritis rendah kurang mampu menginterpretasi, menganalisis, mengevaluasi gagasan.

Dalam penelitian ini diperoleh beberapa temuan adanya kemampuan berpikir kritis pada siswa dengan jawaban-jawaban kritis, antara lain mampu menjawab hubungan antara alat-alat pernapasan dengan peristiwa tersedak. Siswa dengn kemampuan berpikir kritis tinggi menjelaskan alasan terjadinya tersedak karena adanya faring yang merupakan percabangan dua saluran, yaitu saluran tenggorokan yang merupakan saluran pernapasan, dan saluran kerongkongan yang merupakan saluran pencernaan. Jika manusia makan sambil bicara maka saluran pernapasan akan terbuka dan makanan masuk dalam saluran pernapasan. 
Jawaban kritis siswa yang mampu mengaitkan gangguan fungsi pernapasan jika manusia tenggelam. Siswa kritis mampu menjelaskan dengan argumentasi bahwa orang yang tenggelam, paru-parunya banyak kemasukan air sehingga proses pengikatan oksigen di alveoli terhalang (asfisksi). Sejalan dengan pendapat Murwani (2006), bahwa kesadaran kritis akan terbentuk jika siswa merasa bebas dalam berpikir, berpendapat dan mengekspresikan diri dan menerapkan metode ilmiah sehingga memiliki cara berpikir kritis menghadapi masalah sehari-hari dalam kehidupan.

Pendapat Fisher (2009), Eggen dan Kauchak (2012), menjelaskan bahwa berpikir kritis adalah aktivitas terampil yang bisa dilakukan dengan lebih baik dan memenuhi beragam standar pola berpikir, dengan menganalisis, mengkritik untuk mencapai kesimpulan.

3. Pengaruh gaya belajar visual dan kinestetik terhadap prestasi belajar.

Hasil penelitian menunjukkan bahwa terdapat pengaruh yang signifikan antara gaya belajar visual dan kinestetik terhadap prestasi belajar kognitif, afektif dan psikomotorik. Deskripsi data prestasi belajar kognitif, afektif dan psikomotorik berdasrka gaya belajar disajikan pada Tabel 4.

Tabel 4. Deskripsi Data Prestasi Belajar Kognitif, Afektif dan Psikomotor Berdasarkan Gaya Belajar

\begin{tabular}{lrrc}
\hline \multirow{2}{*}{ Gaya Belajar } & \multicolumn{3}{c}{ Rata-rata Prestasi Belajar } \\
& Kognitif & Afektif & Psikomotor \\
\hline Visual & 71,15 & 78,55 & 82,75 \\
Kinestetik & 59,52 & 73,62 & 77,86 \\
\hline \multicolumn{1}{c}{ Sis }
\end{tabular}

Siswa yang dengan gaya belajar visual mempunyai nilai rata-rata prestasi belajar yang lebih baik dari siswa yang mempunyai gaya belajar kinestetik. Hal ini disebabkan simulasi komputer dan model kerja lebih menekankan peranan penting penglihatan (visual). Siswa dengan gaya belajar visual lebih berkonsentrasi dalam menerima pesan yang disampaikan oleh media dengan memusatkan perhatiannya menggunakan indera penglihatan, sehingga cenderung memperoleh rata-rata prestasi kognitif, afektif dan psikomotor yang lebih baik. Hasil penelitian ini didukung oleh penelitian yang dilakukan Mayer and Massa (2003), yang mengungkapkan bahwa gaya belajar visualverbal dapat meningkatkan kemampuan kognitif. Sejalan dengan penelitian Iswari (2011)yang menyimpulan bahwa gaya belajar siswa (visual dan kinestetik) dapat berpengaruh terhadap prestasi belajar siswa.

Siswa dengan gaya belajar kinestetik yang mempunyai karakteristik lebih banyak mengandalkan gerakan dalam proses pembelajaran, kemungkinan kurang berkonsentrasi pada proses pengamatan terhadap media simulasi komputer maupun model kerja, sehingga cenderung memperoleh rata-rata prestasi belajar kognitif, afektif dan psikomotor lebih rendah dari siswa yang mempunyai gaya belajar visual.

Subini (2011) menjelaskan bahwa gaya belajar dipilih seseorang untuk mendapatkan informasi atau pengetahuan dalam suatu proses pembelajaran. Jika diberikan strategi yang sesuai dengan gaya belajarnya, siswa dapat berkembang dengan lebih baik. Menurut Muslich (2007); Sugiarto ( 2011), mengetahui tipe belajar siswa membantu guru untuk dapat mendekati semua atau hampir semua siswanya dengan menyampaikan informasi dengan gaya yang berbeda-beda sesuai dengan tipe belajar siswa dan akan mudah mempelajari hal-hal baru sesuai gaya belajarnya yang dominan.

Temuan yang menarik pada penelitian ini, siswa dengan gaya belajar visual lebih suka meminta mengulangi informasi atau penjelasan yang disampaikan oleh guru. Hal ini dimungkinkan siswa dengan gaya belajar visual kurang peka menggunakan indera pendengarannya. Temuan tentang gaya belajar kinestetik pada penelitian ini, dijumpai siswa yang selalu berusaha memegang benda apapun yang ada di hadapannya, bahkan berusaha memegang peralatan yang dijumpainya meskipun tidak berhubungan dengan materi pelajaran. Siswa lebih tertarik dengan peragaan yang dilakukan pada media simulasi komputer maupun model kerja dengan berusaha mengoperasikan media yang digunakannya. Namun dari 134 siswa yang menjadi sampel penelitian ini hanya terdapat 29 siswa yang mempunyai gaya belajar kinestetik, sehingga hasil penelitian tentang siswa dengan gaya belajar kinestetik kurang mewakili dalam penelitian ini.

4. Pengaruh interaksi antara media dan kemampuan berpikir kritis terhadap prestasi belajar.

Hasil penelitian menunjukkan bahwa interaksi antara media simulasi komputer dan 
model kerja dengan kemampuan berpikir kritis tidak memberikan pengaruh signifikan terhadap prestasi belajar kognitif, afektif dan psikomotor.

Pada penelitian ini tidak menunjukkan hasil seperti yang diharapkan, hal ini kemungkinan terjadi karena: (1) di dalam masyarakat belajar, siswa yang berkemampuan kurang sangat tergantung pada temannya yang lebih pandai sehingga dalam diksusi kelompok hanya siswa-siswa pandai yang aktif mengemukakan pendapat dari hasil pengamatannya dan mengembangkan kemampuan berpikir kritis; (2) ketika membahas materi yang lebih kompleks, guru terlalu banyak memberikan bantuan dan siswa sangat bergantung pada bantuan guru, sehingga strategi scaffolding kurang berperan. Hal ini menyebabkan kemampuan berpikir kritis siswa kurang berkembang.

5. Pengaruh interaksi antara simulasi komputer dan model kerja dengan gaya belajar terhadap prestasi belajar.

Hasil penelitian menunjukkan bahwa terdapat pengaruh yang signifikan dari interaksi simulasi komputer dan model kerja dengan gaya belajar terhadap prestasi belajar kognitif, afektif dan psikomotor. Penggunaan media simulasi dan model kerja memberikan pengaruh yang signifikan terhadap prestasi kognitif, afektif dan psikomotor, karena siswa ikut terlibat dan mendapat pengalaman langsung sehingga menghasilkan prestasi belajar yang maksimal bagi siswa. Aspek kognitif, afektif dan psikomotor terdapat pengaruh yang signifikan antara gaya belajar dan prestasi belajar siswa. Sejalan dengan penelitian yang dilakukan oleh Miller (2001), bahwa teori gaya belajar mengutamakan keterlibatan siswa secara aktif. Deskripsi data prestasi belajar aspek kognitif, afektif dan psikomotorik pada penggunaan media dengan gaya belajar visual dan kinestetik, dan interaksinya ditunjukkan pada Tabel 5 .

Tabel 5. Estimated Marginal Means Interaksi Media dengan Gaya Belajar terhadap Prestasi Belajar

Kognitif, Afektif, dan Psikomotor

\begin{tabular}{llccc}
\multicolumn{4}{c}{ Kognitif, Afektif, dan Psikomotor } \\
\cline { 3 - 5 } Media & Gaya & \multicolumn{3}{c}{ Rata-rata Prestasi Belajar } \\
\cline { 3 - 5 } & Belajar & Kognitif & Afektif & Psikomotor \\
\hline Simulasi & Visual & 68,87 & 77,38 & 81,42 \\
Komputer & Kinestetik & 59.79 & 71,27 & 74,71 \\
Model & Visual & $\mathbf{7 6 , 3 4}$ & $\mathbf{7 9 , 0 2}$ & $\mathbf{8 3 , 2 3}$ \\
Kerja & Kinestetik & 59,07 & 78,04 & 81,29 \\
\hline
\end{tabular}

Kelas yang menggunakan media model kerja pada siswa dengan gaya belajar visual memperoleh prestasi paling tinggi pada prestasi belajar kognitif, afektif, dan psikomotor.

Setelah diinteraksikan antara media dan gaya belajar dengan uji lanjut anava menggunakan Uji Scheffe' dalam tabel post hoc, diperoleh data bahwa, interaksi antara model kerja dan gaya belajar visual dengan media simulasi komputer dan gaya belajar kinestetik ( $p$ value $=0,001)$, dan interaksi antara model kerja dan gaya belajar visual dengan model kerja dan gaya belajar kinestetik ( $p$-value $=0,000)$ memberikan pengaruh yang signifikan terhadap prestasi kognitif.

Interaksikan antara media dengan gaya belajar, diperoleh data bahwa interaksi antara simulasi komputer dan gaya belajar visual dengan simulasi komputer dan gaya belajar kinestetik $(p$-value $=0,000)$, interaksi antara model kerja dan gaya belajar kinestetik dengan simulasi komputer dan gaya belajar kinestetik ( $p$ value $=0,004)$, interaksi antara model kerja dan gaya belajar visual dengan simulasi komputer dan gaya belajar kinestetik $(p$-value $=0,000)$ memberikan pengaruh secara signifikan terhadap prestasi afektif.

Interaksikan antara media dengan gaya belajar, diperoleh data bahwa interaksi antara simulasi komputer dan gaya belajar visual dengan simulasi komputer dan gaya belajar kinestetik $(p$-value $=0,000)$, interaksi antara model kerja dan gaya belajar kinestetik dengan simulasi komputer dan gaya belajar kinestetik ( $p$ value $=0,020)$, interaksi antara model kerja dan gaya belajar visual dengan simulasi komputer dan gaya belajar kinestetik ( $p$-value $=0,000$ ) memberikan pengaruh secara signifikan

terhadap prestasi psikomotor.

6. Pengaruh interaksi antara kemampuan berpikir kritis dengan gaya belajar terhadap prestasi belajar

Hasil penelitian menunjukkan bahwa tidak ada pengaruh yang signifikan dari interaksi antara kemampuan berpikir kritis dan gaya belajar terhadap prestasi belajar kognitif, afektif dan psikomotor

Pada penelitian ini tidak menunjukkan hasil seperti yang diharapkan, hal ini kemungkinan terjadi karena: (1) belum berkembangnya kemampuan berpikir kritis secara optimal, karena siswa terlalu bergantung pada teman dalam satu kelompoknya; (2) terdapat perbedaan yang sangat jauh antara 
jumlah siswa yang mempunyai gaya belajar visual (105 siswa) dengan jumlah siswa yang meliliki gaya belajar kinestetik (29 siswa), sehingga data prestasi belajar siswa dengan gaya belajar kinestetik dimungkinkan belum cukup mewakili dalam penelitian ini.

7. Pengaruh interaksi antara media, kemampuan berpikir kritis dan gaya belajar terhadap prestasi belajar

Hasil penelitian menunjukkan bahwa tidak ada pengaruh yang signifikan dari interaksi media, kemampuan berpikir kritis dan gaya belajar terhadap prestasi belajar kognitif, afektif dan psikomotor

Artinya penggunaan media simulasi komputer dan model kerja, kemampuan berpikir kritis tinggi dan rendah, serta gaya belajar visual dan kinestetik menunjukkan pengaruh faktor tunggal terhadap prestasi belajar koginitif, afektif dan psikomotor. Hal ini kemungkinan terjadi banyak faktor yang mempengaruhi pencapaian prestasi belajar, yaitu: (1) Faktor dalam diri siswa selain kemampuan berpikir kritis dan gaya belajar yang digunakan dalam penelitian ini, seperti kondisi jasmaniah, IQ maupun EQ, minat belajar, motivasi, krativitas dapat menimbulkan masalah namun kurang mendapat perhatian dari guru; (2) Faktor luar yang berpengaruh proses pencapian prestasi belajar selain media pembelajaran, misalnya metode dan model pembelajaran yang dipilih oleh guru, kemungkinan kurang sesuai dengan pembelajaran IPA mengunakan pendekatan kontekstual; (3) adanya keterbatasan dalam penelitian ini sehingga peneliti tidak dapat mengontrol faktor-faktor tersebut di luar kegiatan belajar mengajar.

\section{Kesimpulan dan Rekomendasi}

Berdasarkan hasil penelitian pada materi sistem pernapasan kelas VIII SMP Negeri 3 Magetan Tahun Pelajaran 2012/2013 dan pembahasannya, maka dapat disimpulkan bahwa: 1) Pembelajaran IPA melalui pendekatan kontekstual menggunakan simulasi komputer dan model kerja berpengaruh terhadap prestasi belajar kognitif, afektif dan psikomotor; 2) Kemampuan berpikir kritis tinggi dan rendah berpengaruh terhadap prestasi belajar kognitif, afektif dan psikomotor; 3) Gaya belajar visual dan kinestetik berpengaruh terhadap prestasi belajar kognitif, afektif dan psikomotor; 4) Tidak ada pengaruh yang signfikan dari interaksi antara media dan kemampuan berpikir kritis terhadap prestasi belajar kognitif, afektif dan psikomotor; 5) Ada pengaruh yang signifikan dari interaksi antara media dan gaya belajar terhadap prestasi belajar kognitif, afektif dan psikomotor; 6) Tidak ada pengaruh yang signifikan dari interaksi antara kemampuan berpikir kritis dan gaya belajar terhadap prestasi belajar kognitif, afektif dan psikomotor; 7) Tidak ada pengaruh yang signifikan dari interaksi antara penggunaan media, kemampuan berpikir kritis dan gaya belajar terhadap prestasi belajar kognitif, afektif dan psikomotor.

Berdasarkan kesimpulan dan implikasi hasil penelitian, untuk perbaikan dan peningkatan pembelajaran IPA disarankan: bagi guru, hendaknya faham dengan adanya faktor internal dan eksternal yang mempengaruhi proses pembelajaran dan prestasi belajar, senantiasa memperhatikan perbedaan kemampuan masingmasing siswa. Guru perlu memperhatikan karakteristik setiap materi pelajaran yang akan disampaikan, sehingga dapat menentukan pendekatan, model, metode dan media pembelajaran yang sesuai supaya terjadi peningkatan hasil belajar siswa. Adanya faktor internal siswa yang mempengaruhi prestasi belajar, sebaiknya guru melakukan tes awal atau angket untuk mengetahui perbedaan antara siswa satu dengan yang lainnya.

Bagi Peneliti lain, hasil penelitian ini didapat dari siswa kelas VIII SMP Negeri 3 Magetan tahun Pelajaran 2012/2013, maka perlu dilakukan penelitian di sekolah lain dengan karakteristik permasalahan yang berbeda dari permsalahan yang ada di SMP Negeri 3 Magetan. Kompleksitas materi sistem pernapasan pada manusia yang mencakup aspek biologi, fisika dan kimia akan lebih efektif bila diajarkan dalam bentuk IPA terpadu. Dengan prinsip keterkaitan dan keterpaduan yang dituangkan dalam RPP, SK, KD, materi pelajaran, kegiatan pembelajaran, indikator pencapaian kompetensi, dan sumber belajar dalam satu keutuhan pengalaman belajar yang diterapkan dalam model pembelajaran, yaitu connected, webbed dan integrated. Uji coba instrumen penelitian yang dilakukan di sekolah lain, sebaiknya juga dilakukan pembelajaran oleh peneliti. Dengan harapan validasi instrumen penelitian lebih terkontrol dan lebih signifikan, karena hasil validasi instrumen dijadikan instrumen pada 
pelaksanaan penelitian. Pengukuran variabel moderator hanya dibedakan menjadi dua kategori. Diharapkan pada penelitian selanjutnya variabel dikategorikan lebih rinci. Kemampuan berpikir kritis dibedakan antara tinggi, sedang dan rendah. Gaya belajar dibedakan antara visual, audirorial dan kinestetik. Untuk memperoleh hasil observasi prestasi belajar afektif dan psikomotor yang lebih akurat, diharapkan proses pendokumentasian didukung dengan menggunakan alat rekam yang dapat menyimpan data otentik.

\section{Daftar Pustaka}

Arsyad, A. (2011). Media Pembelajaran. Jakarta: RajaGrafindo Persada.

Depdiknas. (2003). Udang-undang RI Nomor 20 Tahun 2003 Tentang Sistem Pendidikan Nasional. Biro Hukum dan Organisasi Setjen Depdiknas. Jakarta.

Eggen, P. Kauchak, D. (2012). Strategi dan Model Pembelajaran. Jakarta: Indeks.

Fisher, A. (2009). Berpikir Kritis. Jakarta: Erlangga.

Gokhale, AA. (1996). Effectiveness of computer simulation for enhancing higher order thinking. Illinois. Journal of Industrial Teacher Education. 33(4):1-9.

Holzinger, A. Rust, MK. Albert, D. (2008). Dynamic Media in Computer Science Education; Content Complexity and Learning Performance: Is Less More? Educational Technology \& Society. 11(1), 279-290.

Indriana, D. (2011). Ragam Alat Bantu Media Pembelajaran. Yogyakarta: DIVA Press.

Iswari, S. (2010). Pembelajaran biologi metode inkuiri terbimbing menggunakan lab riil dan lab virtual ditinjau dari sikap ilmiah dan gaya belajar. Tesis S2 Program Pendidikan Sains Pascasarjana UNS. Surakarta: (Unpublished).

Lee, H. Plass, JL. Homer, BD. (2006). Optimizing Cognitive Load for Learning ComputerBased Science Science Simulations. New York. J. of Educational Psychology. 98 (4): 902-913.

Mayer, RE. Massa, LJ. (2003). Three Facet of Visual and Verbal Learnes: Cognitif Ability, Cognitif Style, and Learning Preference. Santa Barbara. J. of Educational Psychology. 95 (4): 833-846.

Miller, P. (2001). Learning Styles: The Multimedia of the Mind. Maryland. Educational Resources Information Center (ERIC). 451 140: 2-10.
Murwani, ED. (2006). Peran guru dalam membangun kesadaran kritis siswa. Jakarta. Pendidikan Penabur. 06(V): 59-68.

Muslich, M. (2007). KTSP Pembelajaran Berbasis Kompetensi dan Kontekstual. Jakarta: Bumi Asara.

Oka, AA. (2011) Peningkatan kualitas pembelajaran IPA di SMP melalui pembelajaran kontekstual. Metro. Bioedukasi. 2(1): 81-91.

Purwanto, N. (2009). Prinsip-prinsip dan Teknik Evaluasi Pengajaran. Bandung: Remaja Rosdakarya.

Redhana, IW. (2003). Meningkatkan Keterampilan Berpikikir Kritis Siswa Melalui Pembelajaran Kooperatif Dengan Strategi Pemecahan Masalah. Singaraja. Jurnal Pendidikan dan Pengajaran IKIP Negeri Singaraja. 2 (XXXVI): 1-13.

Sagala, S. (2011). Konsep dan Makna Pembelajaran. Bandung: Alfabeta.

Samani, M. (2007). Menggagas Pendidikan Bermakna. SIC. Surabaya.

Sanaky, H. (2011). Media Pembelajaran. Yogyakarta: Kaukaba Dipantara.

Sanjaya, W. (2011). Strategi Pembelajaran Berorientasi Standar Proses Pendidikan. Jakarta: Prenada Media.

Slavin, RE. (2011). Psikologi Pendidikan. Jakarta: Indeks.

Subini, N. (2011). Rahasia Gaya Belajar Orang Besar. Yogyakarta: Javalitera.

Sudiyono. (2011). Pembelajaran dengan lembar siswa dan media model untuk meningkatkan hasil belajar kompetensi membuat gambar potongan. Semarang. Jurnal Pendidikan Teknik Mesin. 11(2): 84-89.

Sugiarto, I. (2011). Mengoptimalkan Daya Kerja Otak. Jakarta: Gramedia.

Sutjiono, TWA. (2005). Pendayagunaan media pembelajaran. Tasikmalaya. Jurnal Pendidikan Penabur, 04(V):76-84.

Wiyono, K and Taufiq. (2010). Using Computer Simulation To Improve Concept Comphrehension of Physics Teacher Stidents in Sprcial Relativity. Palembang. Proceeding of The Third International Seminar on Science Education: 461-466. 